\title{
HUBUNGAN PENGETAHUAN KEPALA KELUARGA DALAM PENGGUNAAN AIR BERSIH DENGAN KEJADIAN DIARE DI WILAYAH KERJA PUSKESMAS TUTAR KECAMATAN TUTAR KABUPATEN POLEWALI MANDAR TAHUN 2015
}

\begin{abstract}
Muhammad Akbar Salca
Belakang: Penyakit diare merupakan masalah yang sering dihadapi di Indonesia. Masalah ini menjadi semakin serius karena keterlambatan pengambilan tindakan penanggulangannya. Untuk mengurangi permasalahan yang diakibatkan diare diperlukan upaya untuk mengetahui keadaan-keadaan yang menjurus akan terjadinya KLB diare. Beberapa faktor penyebab terjadinya penyakit diare adalah jauhnya jangkauan unit pelayanan kesehatan baik pemerintah maupun swasta, faktor pendidikan dan pengetahuan masyarakat serta perilaku masyarakat dalam menggunakan sarana air bersih dan faktor lingkungan yang belum memenuhi standar kesehatan.Angka penemuan kasus penyakit diare di Kabupaten Polewali Mandar pada tahun 2010 adalah 6.521 orang yang terdiri dari anak umur kurang dari 1 tahun sebanyak 1782 anak, umur $1-4$ tahun sebanyak 2023 anak dan umur 5 tahun ke atas sebanyak 2716 anak. Angka kematian akibat diare sebanyak 4 orang yang terdiri dari bayi umur kurang dari 5 tahun sebanyak 2 orang dan sisanya anak umur lebih dari 5 tahun (Dinkes Polman, 2011) Lokasi penelitian ini bertempat di Wilayah Kerja Puskesmas Tutar yang angka kejadian diare tertinggi diantara puskesmas-puskesmas lainnya selama tahun 2011 yaitu sebanyak 315 kasus. Tingginya angka kejadian diare di Puskesmas Tutar Kecamatan Tutar Kabupaten Polman salah satunya dipengaruhi oleh rendahnya pengetahuan yangdimiliki kebanyakan masyarakat dalam penggunaan air bersih, kurangnya keluarga yang memiliki sumur gali/bor maupun PAM. Kebanyakan masyarakat menggunakan air untuk kehidupan sehari-harinya (mandi, cuci, kakus dan memasak) berasal dari sungai baik musim hujan maupun musim kemarau, dimana air sungai tersebut kurang jernih dan banyak mengandung kotoran (Puskesmas Tutar, 2011). Tujuan penelitian ini adalah mengetahui hubungan pengetahuan kepala keluarga dalam penggunaan air bersih dengan kejadian diare di Puskesmas Tutar Kecamatan Tutar Kabupaten Polman dengan jenis penelitian menggunakan studi cross sectional Populasi penelitian ini adalah seluruh kepala keluarga yang ada di Puskesmas Tutar Kecamatan Tutar Kabupaten Polewali Mandar sebanyak 5057 kepala keluarga. Tekhnik penentuan sampel dalam penelitian ini menggunakan teknik proporsional random sampling, sebanyak 98 responden.
\end{abstract}

\section{Kata kunci : pengetahuan, penggunaan air bersih,diare}

Irritant contact dermatitis is a direct effect of local sitotosik iritanbaik materials physics and chemistry, which are not specific, the epidermal cells with the inflammatory response in the dermis in sufficient time and concentration. (Juanda, S 2009)

The purpose of this study to determine the presence of inflammation decrease in the cocor bebek duck fisherman dermatitis patients in the village of takatidung polewali district polewali mandar district.

Quasy ekperiment, to test the effect of the use of the leaves with a reduction in fishing inflammatory irritant contact dermatitis patients in a comparison test to determine significant influence among the group given and not given cocor bebek.

The population is 2 patients of irritant contact dermatitis in Takatidung Village Polewali District in Polewali Mandar Regency. The sample technique used is Accidental sampling and consists of 2 respondents where 1 resonden is given normal saline and 1 is not given from the first day until the ninth day of respondents who meet the inclusion criteria. The data collection was done by unstructured interview and direct observation to the patient.

Research showed that no effect was given and not given the leaves of cocor duck to decrease inflamasi. This can be seen with a value of $P=0.169$ Paired T test which is less than the significance level $\alpha=0: 05$ 
to show the administration duck cocor not effective in reducing the inflammatory irritant contact dermatitis.

Giving of duck cocor leaves for decreasing inflammation from day to day has a significant change but statistically there is no effect. While the advice recommended for researchers to increase the number of existing samples so that the results are more meaningful and more accurate from this study.

Keywords: Giving Cocor Ducks, Contact Irritant Dermatitis, Paired $T$ Test Literature: 15 books + 2 Journals (2007-2016)

\section{PENDAHULUAN}

Tujuan pembangunan kesehatan pada hakekatnya adalah memuat harapan agar penduduk Indonesia memiliki kemampuan untuk menjangkau pelayanan kesehatan yang bermutu, adil dan merata. Untuk mewujudkan cita-cita tersebut telah dilaksanakan berbagai upaya pembangunan kesehatan dan telah menunjukan perubahan bermakna berupa peningkatan derajat kesehatan masyarakat. Walau demikian berbagai fakta menyadarkan bahwa pelayanan kesehatan yang bermutu, adil dan merata itu masih jauh dari harapan masyarakat dan membutuhkan upaya yang sungguh-sungguh untuk mencapainya.

Salah satu faktor pendukung tingginya angka kesakitan di Indonesia adalah penyakit menular, faktor ini sangat berpengaruh kepada meningkatnya angka kesakitan, salah satu penyakit yang masih menjadi masalah kesehatan masyarakat adalah penyakit diare (Depkes RI, 2002).

Penyakit diare merupakan masalah yang sering dihadapi di Indonesia. Masalah ini menjadi semakin serius karena keterlambatan pengambilan tindakan penanggulangannya. Untuk mengurangi permasalahan yang diakibatkan diare diperlukan upaya untuk mengetahui keadaan-keadaan yang menjurus akan terjadinya KLB diare. (Depkes RI, 2002).

Penyakit diare di Indonesia dewasa ini masih menjadi penyumbang terbesar angka kematian pada anak-anak, disamping disebabkan oleh penyakit lain seperti pnemonia dan ISPA. Beberapa faktor penyebab terjadinya penyakit diare adalah jauhnya jangkauan unit pelayanan kesehatan baik pemerintah maupun swasta, faktor pendidikan dan pengetahuan masyarakat serta perilaku masyarakat dalam menggunakan sarana air bersih dan faktor lingkungan yang belum memenuhi standar kesehatan.
Penyakit diare merupakan salah satu penyebab utama kematian dan kesakitan pada anak-anak di negara berkembang. Diperkirakan di seluruh dunia terjadi 1.000 juta peristiwa diare pada anak balita dengan perkiraan 5 juta kematian setiap tahunnya. Berdasarkan data WHO tahun 2000, dari 15 juta kematian yang diperkirakan terjadi di kalangan anak berusia di bawah lima tahun setiap tahunnya di negara berkembang kira-kira 4 juta kematian $(36,8 \%)$ disebabkan oleh penyakit diare (Depkes RI, 2001).

Berdasarkan hasil Survey Demografi Kesehatan Indonesia (SDKI) tahun 2003, angka kematian akibat diare adalah 2,5 per 1.000 balita, sedangkan untuk semua umur angka kematiannya adalah 5 per 100.000 penduduk. Sekitar $80 \%$ kematian ini terjadi pada dua tahun pertama kehidupan anak. Meskipun demikian penyakit diare bukan hanya didominasi oleh bayi dan balita saja, tetapi juga menyerang semua umur. (Depkes RI, 2004).

Penyakit diare di Sulawesi Barat selama tahun 2010 menunjukan penemuan kasus sebanyak 11,8 juta orang, namun hasil survey penderita diare yang ditemukan hanya 420.000 orang dari perkiraan jumlah penderita hampir 12 juta orang. Penderita diare terbanyak dari golongan umur lebih dari 5 tahun 188.000 anak, kemudian pada usia $1-4$ tahun sebanyak 144.000 anak dan untuk golongan umur kurang dari 1 tahun sebanyak 88.000 anak (Dinkes Sulbar, 2011).

Angka penemuan kasus penyakit diare di Kabupaten Polewali Mandar pada tahun 2010 adalah 6.521 orang yang terdiri dari anak umur kurang dari 1 tahun sebanyak 1782 anak, umur 1 - 4 tahun sebanyak 2023 anak dan umur 5 tahun ke atas sebanyak 2716 anak. Angka kematian akibat diare sebanyak 4 orang yang terdiri dari bayi umur kurang dari 5 tahun sebanyak 2 orang 
dan sisanya anak umur lebih dari 5 tahun (Dinkes Polman, 2011).

Penyakit diare yang terjadi di Wilayah Kerja Puskesmas Tutar Kabupaten Polewali Mandar, ternyata masih menempati urutan teratas. Hal ini sudah terjadi beberapa tahun, sehingga dikatakan bahwa diare merupakan penyakit endemis di Wilayah Kerja Puskesmas Tutar. Angka kejadian diare tersebut selama tahun 2010 adalah sebanyak 150 kasus yang terdiri dari bayi umur $0-1$ tahun sebanyak 100 anak, umur $1-4$ tahun sebanyak 24 anak, dan sisanya umur 5 tahun ke atas sebanyak 26 anak (Puskesmas Tutar, 2011).

Masih tingginya angka kejadian penyakit diare di Wilayah Kerja Puskesmas Tutar Kabupaten Polman disebabkan oleh beberapa faktor antara lain kesehatan lingkungan, keadaan gizi, kependudukan, pendidikan, keadaan sosial ekonomi, dan perilaku masyarakat yang secara langsung maupun tidak langsung mempengaruhi angka kejadian penyakit diare. Saat ini teknik penatalaksanaan dan pencegahan penyakit diare sudah dapat dikuasai, akan tetapi untuk mencegahnya selain dengan teknik yang baik juga harus didukung dengan sarana yang memadai untuk pengobatannya. Disamping itu masih banyak faktor-faktor lain yang mempengaruhinya, terutama masalah pengetahuan masyarakat dalam penggunaan air bersih.

Lokasi penelitian ini bertempat di Wilayah Kerja Puskesmas Tutar yang angka kejadian diare tertinggi diantara puskesmas-puskesmas lainnya selama tahun 2011 yaitu sebanyak 315 kasus. Tingginya angka kejadian diare di Puskesmas Tutar Kecamatan Tutar Kabupaten Polman salah satunya dipengaruhi oleh rendahnya pengetahuan yang dimiliki kebanyakan masyarakat dalam penggunaan air bersih, kurangnya keluarga yang memiliki sumur gali/bor maupun PAM. Kebanyakan masyarakat menggunakan air untuk kehidupan sehari-harinya (mandi, cuci, kakus dan memasak) berasal dari sungai baik musim hujan maupun musim kemarau, dimana air sungai tersebut kurang jernih dan banyak mengandung kotoran. Selain daripada itu masyarakat juga kurang memperhatikan kebersihan lingkungan tempat tinggalnya (Puskesmas Tutar, 2011).
Pada studi pendahuluan yang dilaksanakan pada tanggal 24 - 25 Desember 2011 terhadap 30 kepala keluarga dengan menggunakan teknik wawancara mengenai hubungan pengetahuan kepala keluarga dalam penggunaan air bersih dengan kejadian diare, diperoleh hasil sebanyak 30 kepala keluarga memiliki pengetahuan dalam penggunaan air bersih kurang, dan sisanya sebanyak 6 kepala keluarga memiliki pengetahuan dalam penggunaan air bersih baik. Pengetahuan merupakan faktor yang sangat penting untuk terbentuknya tindakan masyarakat dalam penggunaan air bersih. Pengetahuan yang didasari dengan pemahaman yang tepat akan menumbuhkan sikap yang positif sehingga sekiranya tumbuh satu bentuk prilaku baru yang diharapkan dalam penggunaan air bersih.

Berdasarkan uraian yang dikemukakan di atas, Peneliti tertarik untuk melaksanakan penelitian yang akan dituangkan dalam bentuk skripsi dengan judul "Hubungan Pengetahuan Kepala Keluarga dalam Penggunaan Air Bersih dengan Kejadian Diare di Puskesmas Tutar Kecamatan Tutar Kabupaten Polman".

\section{METODE PENELITIAN Jenis dan Metode Penelitian}

Jenis penelitian yang digunakan pada penelitian ini adalah deskriptif analitik yaitu penelitian yang dilakukan untuk menganalisis dan menyajikan data secara sistematis sehingga dapat lebih mudah untuk dipahami dan disimpulkan (Badriah, 2006 : 16).

Rancangan atau desain penelitian yang digunakan dalam penelitian ini adalah cross sectional, yaitu suatu cara penelitian deskriptif yang dilakukan terhadap sekumpulan objek yang biasanya cukup banyak dalam jangka waktu tertentu dan waktu pengukurannya dilakukan hanya sekali pada saat pengukuran (Notoatmodjo, 2005 : 140).

\section{Lokasi dan Waktu Penelitian}

Penelitian ini dilaksanakan di Puskesmas

Tutar Kabupatem Polewali Mandar dan dilaksanakan pada bulan Maret sampai dengan Juni 2012 .

\section{Populasi dan Sampel}

Populasi

Populasi pada penelitian ini adalah seluruh kepala keluarga yang ada di Puskesmas Tutar Kecamatan Tutar Kabupaten 
Polewali Mandar sebanyak 5057 kepala keluarga..

Sampel

\section{HASIL DAN PEMBAHASAN}

Hasil Penelitian

Penelitian mengenai hubungan pengetahuan kepala kuluarga dalam penggunaan air bersih dengan kejadian diare di wilayah kerja Puskesama Tutar Kabupaten Polewali Mandar, dilaksanakan selama Dua bulan mulai bulan Maret sampai dengan Mei 2015. Berdasarkan hasil pengolahan data yang telah dilakukan dan disesuaikan dengan tujuan
Sampel sebanyak 98 kepala keluarga di Wilayah Kerja Puskesmas Tutar Kecamatan Tutar Kabupaten Polewali Mandar

penelitian maka diperoleh hasil yang disusun dalam bentuk tabel sebagai berikut :

Analisa Univariat

Analisa univariat dalam penelitian ini akan menggambarkan data demografi resonden meliputi umur, pekerjaan, tingkat pendidikan, pengetahuan kepala keluarga serta kejadian diare.

Tabel 4.1 Distribusi Responden Menurut umur kepala keluarga di Wilayah Kerja Puskesmas Tutar Kabupaten Polewali Mandar 2015

\begin{tabular}{|c|c|c|}
\hline Umur & f & $\%$ \\
\hline$<20$ tahun & 6 & 4.0 \\
\hline $20-35$ & 14 & 18.7 \\
\hline$>35$ & 58 & 77.3 \\
\hline Total & 98 & 100.0 \\
\hline
\end{tabular}

Sumber : Data Primer, 2015

Berdasarkan tabel 4.1 dari 78 / kepala keluarga yang menjadi responden di puskesmas Tutar dominan yang berumur $>35$ tahun sebanyak 58 responden $(77.3 \%)$ sedangkan yang berusia 20 35 tahun sebanyak 14 orang responden $(18,7 \%)$

dan sisanya 6 orang responden $(4,0 \%)$ berumur $<$ 20. Pada penelitian ini apabila dilihat dari factor usia kabanyakan berusia 20-35 tahun, itu berarti mereka kebanyakan pada usia subur dan produktif.

Tabel : 4.2 Distribusi responden menurut tingkat pendidikan di Wilayah Kerja Puskesmas Tutar Kabupaten Polewali Mandar 2015

\begin{tabular}{ccc}
\hline $\begin{array}{c}\text { Tingkat } \\
\text { Pendidikan }\end{array}$ & f & \% \\
\hline SD & 27 & 27.6 \\
SMP & 8 & 8.2 \\
T.SD & 63 & 64.2 \\
\hline Total & 98 & 100.0 \\
\hline
\end{tabular}

Sumber : Data Primer, 2015

Pada tabel 4.2 menunjukkan bahwa dari 98 responden dengan latar belakang pendidikan tidak tamat Sekolah Dasar/ SD yaitu sebanyak 63 responden $(64.2 \%)$, sedangkan yang tamat SD sebanyak 27 responden $(27,6 \%)$, dan

mencapai tingkat pendidikan Sekolah Menengah Pertama Atau SMP sebanyak 8 responden (8.2\%). Ini menunjukkan rata-rata tingkat pendidikan masyarakat di wilayah puskesmas Tutar masih sangat rendah.

Tabel 4.3 Distribusi Responden Menurut Pekerjaan di Wilayah Kerja Puskesmas Tutar Kabupaten Polewali Mandar 2015

\begin{tabular}{lll} 
Jenis Pekerjaan & f & $\%$ \\
\hline
\end{tabular}




\begin{tabular}{|c|c|c|}
\hline Petani & 40 & 40.8 \\
\hline Swasta & 30 & 30.6 \\
\hline Tidak Bekerja & 28 & 28.6 \\
\hline Total & 98 & 100.0 \\
\hline \multirow{2}{*}{\multicolumn{3}{|c|}{$\begin{array}{l}\text { Sumber: Data Primer, } 2015 \\
\text { Pada tabel } 4.3 \text { menunjukkan bahwa dari } 98 \\
\text { responden, jenis pekerjaan yang paling banyak } \\
\text { adalah petani sebanyak } 40 \text { responden }(40.8 \%) \text {, } \\
\text { Tabel : 4.4 Distribusi responden menurut Pengetahua } \\
\text { kerja Puskesmas Tutar kabupaten Polewali Mandar } 2\end{array}$}} \\
\hline & & \\
\hline $\begin{array}{l}\text { Pengetahuan tentang } \\
\text { Pengertian air bersih }\end{array}$ & f & $\%$ \\
\hline Baik & 20 & 20.00 \\
\hline Cukup & 56 & 57.90 \\
\hline Kurang & 22 & 22.10 \\
\hline Total & 98 & 100.0 \\
\hline
\end{tabular}

Sumber : Data Primer, 2015

Pada tabel 4.4 menunjukkan bahwa dari 98 responden, sebagian besar kepala keluarga memiliki tingkat pengetahuan tentang pengertian air bersih sudah cukup yaitu sebanyak 56

dan swasta sebanyak 30 responden $(30.6 \%)$, sedangkan yang tidak bekerja sebanyak 28 responden

$(28.6 \%)$.

Tabel : 4.5 Distribusi responden menurut tingkat Pengetahuan tentang syarat air bersih di wilayah kerja Puskesmas Tutar kabupaten Polewali Mandar 2015

\begin{tabular}{lcc}
\hline $\begin{array}{c}\text { Pengetahuan tentang } \\
\text { syarat air bersih }\end{array}$ & f & \% \\
\hline Baik & 18 & 18.95 \\
Cukup & 21 & 21.05 \\
Kurang & 59 & 60.00 \\
\hline \multicolumn{1}{c}{ Total } & 98 & 100.0 \\
\hline
\end{tabular}

Sumber : Data Primer, 2015

Pada tabel 4.5 menunjukkan bahwa dari 98 responden, sebagian besar kepala keluarga memiliki tingkat pengetahuan tentang syarat air bersih masih kurang yaitu sebanyak 59

responden $(57.90 \%)$, tingkat pengetahuan baik sebanyak 20 responden $(20.00 \%)$, sedangkan tingkat pengetahuan kurang yaitu sebanyak 22 responden $(22.10 \%)$.

Tabel : 4.6 Distribusi responden menurut tingkat Pengetahuan tentang sumber air bersih di wilayah kerja Puskesmas Tutar kabupaten Polewali Mandar 2015

\begin{tabular}{ccc}
\hline $\begin{array}{c}\text { Pengetahuan } \\
\text { tentang Sumber air } \\
\text { bersih }\end{array}$ & f & $\%$ \\
\hline Baik & 19 & 18.95 \\
\hline
\end{tabular}




\begin{tabular}{ccc} 
Cukup & 57 & 58.95 \\
Kurang & 22 & 22.10 \\
\hline Total & 98 & 100.0 \\
\hline $\begin{array}{l}\text { Sumber : Data Primer, 2015 } \\
\text { Pada tabel 4.6 menunjukkan } \\
\text { responden, sebagian besar } \\
\text { memiliki tingkat pengetahuan tentang sumber air } \\
\text { bersih sudah cukup yaitu sebanyak 57 responden }\end{array}$ & $\begin{array}{l}\text { kepala } \\
\text { keluarga }\end{array}$ \\
$\begin{array}{l}\text { Tabel : 4.7 Distribusi responden menurut tingkat Peng } \\
\text { wilayah kerja Puskesmas Tutar kabupaten Polewali M }\end{array}$ \\
\hline $\begin{array}{l}\text { Pengetahuan tentang } \\
\text { pengolahan air } \\
\text { bersih }\end{array}$ & $\mathbf{f}$ & \% \\
\hline $\begin{array}{l}\text { Baik } \\
\text { Cukup }\end{array}$ & 22 & 22.10 \\
\hline $\begin{array}{l}\text { Kurang } \\
\text { Total }\end{array}$ & 20 & 21.05 \\
\hline
\end{tabular}

Sumber : Data Primer, 2015

Pada tabel 4.7 menunjukkan bahwa dari 98 responden, sebagian besar kepala keluarga memiliki tingkat pengetahuan tentang syarat air bersih masih kurang yaitu sebanyak 56

(58.95\%), tingkat pengetahuan kurang sebanyak 22 responden $(22.10 \%)$, sedangkan tingkat pengetahuan baik yaitu sebanyak 19 responden $(18.95 \%)$.

Tabel : 4.8 Distribusi responden menurut tingkat Pengetahuan di wilayah kerja Puskesmas Tutar kabupaten Polewali Mandar 2015

\begin{tabular}{lcc}
\hline Pengetahuan & f & \% \\
\hline Baik & 6 & 6.1 \\
Cukup & 44 & 44.9 \\
Kurang & 48 & 49.0 \\
\hline \multicolumn{1}{c}{ Total } & $\mathbf{9 8}$ & $\mathbf{1 0 0 . 0}$ \\
\hline
\end{tabular}

Sumber : Data Primer, 2015

Pada tabel 4.8 menunjukkan bahwa dari 98 responden, sebagian besar kepala keluarga memiliki tingkat pengetahuan yang masih kurang yaitu sebanyak 48 responden $(49.0 \%)$, responden $(56.85 \%)$, tingkat pengetahuan cukup sebanyak 20 responden (21.05\%), sedangkan tingkat pengetahuan baik yaitu sebanyak 22 responden $(22.10 \%)$.

tingkat pengetahuan cukup sebanyak 44 responden (44.9\%), sedangkan tingkat pengetahuan baik yaitu sebanyak 6 responden $(6.1 \%)$. 
Tabel : 4.9 Distribusi Responden Menurut kejadian diare di wilayah kerja puskesmas Tutar Kabupaten Polewali Mandar 2015

\begin{tabular}{ccc}
\hline Kejadian Diare & f & \% \\
\hline Menderita & 68 & 69.4 \\
Tidak menderita & 30 & 30.6 \\
\hline Total & 98 & 100.0
\end{tabular}

\section{Sumber : Data Primer, 2015}

Pada tabel 4.9 menunjukkan bahwa dari 98 responden, yang menderita diare yaitu sebanyak 68 responden $(69.4 \%)$, sedangkan yang tidak menderita yaitu hanya 30 responden $(30,6 \%)$. PEMBAHASAN

Berdasarkan hasil analisis data dan disesuaikan dengan tujuan penelitian serta kerangka konsep penelitian, maka pembahasan di kemukakan sebagai berikut :

Analisis hubungan pengetahuan kepala keluarga dalam penggunaan air bersih dengan kejadian diare di Puskesmas Tutar Kecamatan Tutar Kabupaten Polewali Mandar.

Pengetahuan Kepala keluarga terkait dengan sikap atau perbuatan melakukan sesuatu dalam kehidupannya. Menurut Bloom yang dikutip oleh Ngatimin, pengetahuan merupakan bagian dari knowledge, application, analysis, dan evaluation, dimana pengetahuan sangat penting dalam memberikan wawasan terhadap sikap atau perbuatan seseorang.

Pengetahuan merupakan faktor yang sangat penting untuk terbentuknya tindakan seseorang. Karena jika seseorang tidak mengetahui sebuah obyek, obyek tersebut tidak akan menarik bagi seseorang. Begitu juga dengan kejadian diare, pada saat responden tidak mengetahui tentang penyebab diare dalam hal ini penggunaan air bersih baik defenisi, syarat, sumber dan pengolahan air bersih, maka responden, akan memandang sebelah mata terhadap fungsi dan manfaat air bersih Padahal Penggunaan air bersih mempunyai dampak pada kebersihan makanan dan minuman serta higiene perseorangan. Penggunaan air bersih berpengaruh baik terhadap kesehatan.

Pada tabel 4.8 menunjukkan bahwa dari 98 responden, sebagian besar kepala keluarga memiliki tingkat pengetahuan yang masih
Dimana hal ini berkaitan dengan pengetahuan masyarakat tentang penyebab diare masih dangat kurang.

kurang yaitu sebanyak 48 responden (49.0\%), tingkat pengetahuan cukup sebanyak 44 responden $(44.9 \%)$, sedangkan tingkat pengetahuan baik yaitu sebanyak 6 responden (6.1\%). Dengan demikian responden dengan tingkat pengetahuan kurang lebih banyak dibandingkan dengan responden dengan tingkat pengetahuan cukup dan dan baik.

Menurut pengamatan peneliti, tahu atau tidak kepala keluarga tentang pengunaan air bersih dipengaruhi oleh berbagai faktor, salah satu diantaranya yaitu kurangnya informasi tentang pelayanan kesehatan di puskesmas baik itu diposyandu maupun di puskesmas itu sendiri. Latar belakang pendidikan dapat mempengaruhi sikap seseorang dalam mengambil keputusan. Berdasarkan distribusi pendidikan responden mayoritas latar belakang pendidikan masyarakat yang ada di wilayah Tutar menunjukkan tingkat pendidikan yang masih sangat rendah dengan presentase pada tabel 4.2 yaitu dari sejumlah responden yang diteliti yang mempunyai tingkat pendidikan tidak tamat Sekolah Dasar/ SD yaitu sebanyak 63 responden (64.2\%), sedangkan yang tamat SD sebanyak 27 responden $(27,6 \%)$, dan mencapai tingkat pendidikan Sekolah Menengah Pertama Atau SMP hanya 8 responden $(8.2 \%)$. Sama halnya dengan pencegahan diare dimana Berdasarkan hasil penelitian mengatakan semakin rendah latar belakang pendidikan kecenderungan terjadi penolakan terhadap pengambilan sebuah keputusan yang dianggap tidak bernilai, hal ini faktor terpenting dari kejadian diare. Pengetahuan tentang penggunaan air bersih seperti syarat air bersig sumber air bersig sampai 
dengan pengolahan air bersih tergantung oleh banyaknya orang yang mendengar, melihat, mengikuti penyuluhan-penyuluhan oleh tenaga kesehatan, tokoh masyarakat dan sebagainya. Dengan pengetahuan diharapkan dapat mempengaruhi persepsi, sikap dan perilaku untuk lebih menerima dan mempunyai kemauan untuk mengimunisasikan bayi mereka untuk mewujudkan tujuan dari pemerintah dalam meningkatkan kesehatan individu, keluarga dan masyarakat.

Sesuai dengan prinsip teknologi tepat guna di pedesaan maka air minum yang berasal dari mata air dan sumur dalam dapat diterima sebagai air yang sehat dan memenuhi syarat sehat, asalkan tidak tercemar oleh kotoran terutama kotoran manusia dan binatang. Hal ini berbeda dengan penggunaan air di wilayah tutar yang mayoritas masyarakat memperoleh air untuk keperluan sehari-hari dari aliran sungai yang digunakan untuk mandi, mencuci dan dikomsumsi untuk keperluan minum (termasuk untuk memasak). (Puskesmas tutar, 2012)

Berdasarkan distribusi pengetahuan kepala keluarga tentang syarat air bersih yaitu sebagian besar kepala keluarga memiliki tingkat pengetahuan masih kurang yaitu sebanyak 59 responden $(60.00 \%)$, dibandingkan dengan yang berpengetahuan cukup sebanyak 21 responden $(21.05 \%)$, sedangkan pengetahuan baik yaitu sebanyak 18 responden (18.95\%). Notoatmodjo (2002, 153) menyatakan bahwa agar air minum tidak menyebabkan penyakit, maka air tersebut hendaknya diusahakan memenuhi persyaratanpersyaratan kesehatan.

Menurut Notoatmodjo (2002 : 155 158) ada beberapa cara pengolahan air minum salah satunya adalah Pengolahan Air dengan Memanaskan sampai Mendidih. Tujuannya untuk membunuh kuman-kuman yang terdapat pada air. Pengolahan semacam ini lebih cepat hanya untuk konsumsi kecil, misalnya untuk kebutuhan rumah tangga. Namun Berdasarkan distribusi responden/ kepala keluarga yang memilki pengetahuan tentang pengolahan air bersih masih kurang yaitu sebanyak 56 responden $(56.85 \%)$. Pengolahan air yang benar seringkali diabaikan oleh masyarakat khususnya yang berada di wilayah tutar yang umumnya mempunyai Sumber air minum dari sungai yang jelas tidak terlindungi (protected), sehingga air tersebut tidak atau kurang memenuhi persyaratan kesehatan. Perlu pengolahan terlebih dahulu sehingga Hal ini perlu perhatian khusus dari petugas setempat.

Dari hasil penelitian yang menggunakan uji chi-square dengan tingkat kepercayaan $\alpha<$ 0,05 didapatkan ada hubungan antara tingkat pengetahuan kepala keluarga dengan kejadian Diare dengan $p$-Value 0,000 .

Beberapa hal yang mempengaruhi penyakit Diare adalah pengetahuan Kepala keluarga sesuatu yang diketahui kepala keluarga tentang penyakit Diare, baik melalui tanda-tanda yang terlihat pada penderita, penyebab diare termasuk mengenai penggunaan air bersih serta pertolongan pertama, informasi maupun tempat pelayanan.

Pengetahuan adalah hal yang penting bagi setiap individu, karena modal pengetahuan seseorang bila bersikap atau melakukan sesuatu usaha termasuk melakukan usaha pencegahan dari berbagai penyakit seperti Diare. Hal ini perlu ditunjang oleh sejauh mana tingkat pengetahuan kepala keluarga agar permasalahan dapat dipahami.

Pada Tabel 4.10 didapatkan bahwa dari 98 responden yang menderita diare, persentase tertinggi adalah kategori pengetahuan kurang yaitu sebanyak 46 responden (67.6\%), jika dibandingkan dengan kategori pengetahuan cukup yaitu sebanyak 22 responden (32.4\%) sedangkan yang berpengetahuan baik tidak ada atau $(0 \%)$. Sedangkan dari 30 responden yang tidak menderita diare, persentase tertinggi adalah kategori pengetahuan cukup yaitu sebanyak 22 responden (37.2\%), jika dibandingkan dengan kategori pengetahuan baik sebanyak 6 responden $(20.0 \%)$ dan yang berpengetahuan kurang yaitu sebanyak 2 responden $(6.8 \%)$.

Berdasarkan hasil penelitian diketahui bahwa pada umumnya responden memiliki pengetahuan tentang penggunaan air bersih yang kurang terhadap kejadian diare pada keluarga

Hasil penelitian ini didukung oleh teori Kambu (2005) yang menyatakan bahwa memang ada hubungan antara pengetahuan dengan kejadian Diare. Responden yang memiliki pengetahuan baik akan mencegah timbulnya penyakit Diare pada keluarga dari 
pada responden yang memiliki pengetahuan kurang.

Menurut teori Asrul (2003) bahwa individu akan sadar, tahu, mengerti, serta mau melakukan suatu anjuran yang berhubungan dengan kesehatan. Betapa pentingnya pengetahuan orang tua untuk Balita guna merubah perilaku, maka orang tua akan lebih mudah termotivasi untuk melakukan sesuatu yang positif untuk dirinya.

\section{KESIMPULAN DAN SARAN \\ Kesimpulan}

Dari hasil penelitian tentang "Hubungan pengetahuan kepala keluarga dalam penggunaan air bersih dengan kejadian diare di wilayah kerja Puskesmas Tutar Kabupaten Polewali Mandar tahun 2012" yang dilakukan pada tanggal 05 Maret sampai dengan Mei 2012 dengan jumlah sampel 98 responden. Dapat disimpulkan sebagai berikut :

Pengetahuan responden tentang pengertian air bersih sudah cukup yaitu sebanyak 56 responden $(57.90 \%)$, tingkat pengetahuan baik sebanyak 20 responden (20.00\%), sedangkan tingkat pengetahuan kurang yaitu sebanyak 22 responden $(22.10 \%)$.

sebagian besar kepala keluarga memiliki tingkat pengetahuan tentang syarat air bersih masih kurang yaitu sebanyak 59 responden $(60.00 \%)$, tingkat pengetahuan cukup sebanyak 21 responden $(21.05 \%)$, sedangkan tingkat pengetahuan baik yaitu sebanyak 18 responden (18.95\%).

Kepala keluarga yang memiliki tingkat pengetahuan tentang sumber air bersih sudah cukup yaitu sebanyak 57 responden $(58.95 \%)$, tingkat pengetahuan kurang sebanyak 22 responden $(22.10 \%)$, sedangkan tingkat pengetahuan baik yaitu sebanyak 19 responden (18.95\%).

Sedangkan kepala keluarga memiliki tingkat pengetahuan tentang syarat air bersih masih kurang yaitu sebanyak 56 responden $(56.85 \%)$, tingkat pengetahuan cukup sebanyak 20 responden (21.05\%), sedangkan tingkat pengetahuan baik yaitu sebanyak 22 responden $(22.10 \%)$.

Sebanyak 98 responden, yang menderita diare yaitu sebanyak 68 responden (69.4\%), sedangkan yang tidak menderita yaitu hanya 30 responden $(30,6 \%)$. Dimana hal ini berkaitan dengan pengetahuan masyarakat tentang penyebab diare masih dangat kurang.

Ada hubungan antara Pengetahuan kepala keluarga dalam penggunaan air bersih dengan kejadian diare diwilayah kerja puskesmas Tutar. Hasil analisa data dengan menggunakan uji chi-square maka di peroleh hasil $\alpha 0,05$ lebih besar $\mathrm{p}=0,000$ Saran maka ini berarti $\mathrm{H}_{1}$ di terima dan $\mathrm{H}_{0}$ ditolak

\section{Bagi Puskesmas}

Diharapkan kepada pihak Puskesmas Tutar Kabupaten Polewali Mandar agar menambah unit pelayanan kesehatan secara merata yang dapat dijangkau oleh masyarakat.

Diharapkan kepada pihak Puskesmas Tutar Kabupaten Polewali Mandar untuk memberikan penyuluhan-penyuluhan kesehatan khususnya mengenai pegolahan air bersih agar dapat meningkatkan pelayanan kesehatan pada masyarakat dan terhindar dari penyakit diare

Bagi Responden

Bagi masyarakat di Kecamatan Tutar agar mengelolah air menjadi layak untuk dikomsumsi sehingga terhindar dari ,berbagaimacam penyakit khususnya diare.

\section{DAFTAR PUSTAKA}

Arikunto Suharsimi, (1999). Prosedur Penelitian, Suatu Pendekatan Praktek, Jakarta : Rineka Cipta.

Bachtiar, (2002). Metodologi Penelitian Kesehatan. Jakarta : Universitas Indonesia.

Badriah, (2006). Metodologi Penelitian Ilmuilmu Kesehatan. Bandung : Multazam.

Depkes RI, (2000). Bimbingan dalam Tatalaksana Penderita Diare Pada Anak. Jakarta : Direktorat Jenderal P2M dan PLP.

(2001). Berita Epidemiologi Bulletin, Edisi April, 7 - 8, Jakarta. 
(2002). Pedoman Pemberantasan

Penyakit Diare. Jakarta : Direktorat Jenderal P2M dan PLP.

(2002). Manajemen Terpadu Balita

Sakit Seri $1-8$, Jakarta.

(2003). Panatalaksanaan Penyakit

Diare. Jakarta : Direktorat Jenderal

P2M dan Penyehatan Lingkungan

Pemukiman.

(2002). Pentingnya Kemitraan

Dalam Penanggulangan Diare. Jakarta

: Direktorat Jenderal P2M dan

Penyehatan Lingkungan Pemukiman.

(2003). Survei Kesehatan Rumah

Tangga, Jakarta.

Dinkes Kabupaten Ciamis, (2007). Profil Kesehatan Kabupaten Ciamis Tahun 2007, Ciamis.

Dinkes Propinsi Jawa Barat, (2007). Profil Kesehatan Propinsi Jawa Barat Tahun 2007, Bandung.

Puskesmas Pamarican, (2007), Profil Kesehatan Puskesmas Pamarican Tahun 2007. Ciamis.

Sekolah Tinggi Ilmu Kesehatan Bina Putera Banjar (2008). Panduan Penyusunan dan Penulisan Skripsi/Riset Tahun Akademik 2008 - 2009. Banjar.

Sugiyono, (2004). Statistika Penelitian dan Aplikasinya dengan SPSS 10,00 For Window, Bandung: Alfabeta.

(2005). Metode Penelitian Administrasi. Bandung : Alfabeta.

Soekidjo Notoatmodjo, (2000). Sikap dan Perilaku Kesehatan. Jakarta : Rineka Cipta.

, (2002). Metodologi Penelitian Kesehatan. Jakarta : Rineka Cipta. , (2003). Ilmu Kesehatan Masyarakat (Prinsip-prinsip Dasar). Jakarta : Rineka Cipta. , (2007). Promosi Kesehatan \& Ilmu Perilaku. Jakarta : Rineka Cipta.

Umar, Husein, (2004). Metode Penelitian Untuk Skripsi dan Tesis Bisnis. Jakarta : Rajawali Pers.

Widjaja, M.C, (2003). Mengatasi Diare dan Keracunan pada Balita. Jakarta : Kawan Pustaka. 